\title{
INFLUENCE OF BILL SHAPE ON ECTOPARASITE LOAD IN WESTERN SCRUB-JAYS
}

\author{
Brett R. Moyer ${ }^{1}$, A. Townsend Peterson ${ }^{2}$ And Dale H. Clayton ${ }^{1,3}$ \\ ${ }^{1}$ Department of Biology, University of Utah, 257 South 1400 East, Salt Lake City, UT 84112-0840 \\ ${ }^{2}$ Natural History Museum, University of Kansas, Lawrence, KS 66045
}

\begin{abstract}
Populations of the Western Scrub-Jay (Aphelocoma californica) have bills specialized for feeding in their respective habitats. Populations in oak habitat have hooked bills, whereas those in pinyon habitat have pointed bills with a reduced maxillary overhang. Work on other bird species shows that the bill overhang is essential for efficient preening to control ectoparasites. Given the importance of this overhang, we predicted that louse-infested jays with pointed bills would have higher louse loads than those with hooked bills. We compared the number of lice on 65 pointed-billed (4 infested) and 105 hooked-billed (17 infested) birds. Despite their lower incidence of louse infestation, pointed-billed birds had significantly more lice than hooked-billed birds, supporting our predic-
\end{abstract}

Manuscript received 5 September 2001; accepted 24 April 2002.

${ }^{3}$ Corresponding author. E-mail: clayton@biology. utah.edu tion. While pointed bills enhance feeding in pinyon habitat, our results suggest that they may incur a cost of reduced preening efficiency. Evolution of bill shape has traditionally been interpreted mainly in terms of foraging. Our results suggest that selection for efficient preening may also play an important role.

Key words: Aphelocoma californica, bill shape, ectoparasite, lice, preening, Western Scrub-Jay.

Influencia de la Forma del Pico en la Carga de Ectoparásitos en Aphelocoma californica

Resumen. Los individuos de distintas poblaciones de Aphelocoma californica tienen picos especializados para alimentarse en sus hábitats respectivos. Las poblaciones de hábitats con robles se caracterizan por picos ganchudos, mientras que las de hábitats con piñones tienen picos puntiagudos, con el gancho de la punta de la maxila reducido. Estudios en otras especies de aves han mostrado que el gancho del pico es esencial para acicalarse eficientemente y así controlar los 
ectoparásitos. Dada la importancia de este gancho, predijimos que los individuos de $A$. californica de pico puntiagudo infestados con piojos de pluma tendrían una mayor carga de ectoparásitos que aquellos de pico ganchudo. Comparamos el número de piojos entre 65 individuos de pico puntiagudo (4 infestados) y 105 de pico ganchudo (17 infestados). A pesar de la baja incidencia de infestación por piojos, las aves de pico puntiagudo presentaron significativamente más piojos que las de picho ganchudo, apoyando nuestra predicción. Aunque los picos puntiagudos benefician la alimentación en hábitats de piñones, nuestros resultados sugieren que podrían representar un costo reduciendo la eficiencia de acicalamiento. Por lo general, la evolución de la forma del pico ha sido interpretada tradicionalmente en términos del forrajeo, pero nuestros resultados sugieren que la selección para acicalarse eficientemente también podría tener un papel importante.

The adaptive significance of bill morphology has been studied extensively in relation to foraging (Grant 1986, Smith 1987, Benkman and Lindholm 1991, Peterson 1993). Other functions of the bill have received considerably less attention. For example, bills are also important tools for preening. Daily preening is required for straightening and oiling feathers and removing dirt and debris from the body surface (Campbell and Lack 1985). Preening is also critical for defense against ectoparasites; birds with experimentally impaired preening abilities are subject to rapid increases in feather lice (Brown 1972, Clayton 1991), which can lead to reduced survival (Clayton et al. 1999) and mating success (Clayton 1990). Increases in louse load also occur on wild birds with minor bill deformities that prevent full occlusion of the mandibles, which is necessary for efficient preening (Pomeroy 1962, Clayton et al. 1999). Many other studies of birds have shown detrimental effects of other ectoparasites on fitness (Møller et al. 1990, Loye and Zuk 1991, Lehmann 1993, Clayton and Moore 1997). Since many of these ectoparasites are controlled by preening, they are potential agents of selection on bill morphology.

Comparative and experimental studies show that particular features of bill shape, such as the maxillary overhang, are critical for parasite control. For example, comparative analyses of 52 species of Peruvian birds demonstrated a significant negative correlation between louse abundance and the degree to which the upper mandible overhangs the lower mandible (Clayton and Walther 2001). This correlation suggests that species of birds with relatively long bill overhangs are better at controlling lice by preening. (Extreme overhangs, such as the hooked bills of raptors and parrots, are adaptations mainly for feeding and do little to improve preening efficiency). A relationship between length of the bill overhang and louse abundance has also been confirmed by experiments in which removal of the (1-2 mm) overhang of Rock Doves (Columba livia) triggers a dramatic increase in louse abundance (Moyer et al., in press).

A bill shape that enhances feeding efficiency may compromise preening efficiency. Murray (1990) suggested that birds with smaller bills can remove ectoparasites better than birds with elongated or special- ized bills. Clayton and Walther (2001), however, found no relationship between bill size and louse load. The apparent reason is that birds with long bills compensate by scratching more with their feet (Clayton and Cotgreave 1994). Scratching is another effective defense against ectoparasites that most birds rely upon for controlling ectoparasites on regions they cannot preen, such as the head (Clayton 1991). Birds with inefficient preening may also compensate by using other defenses such as sunning and dusting behavior (Moyer et al., in press). If compensatory defenses are not as efficient as preening, however, inefficient preeners may still have more ectoparasites than birds with efficient bills.

Populations of the Western Scrub-Jay (Aphelocoma californica) have bills specialized for feeding in their respective habitats (Peterson 1993, Bardwell et al. 2001). Scrub-jay populations in oak habitat have relatively deep, hooked bills, whereas those in pinyon habitat have relatively shallow, pointed bills with a reduced maxillary overhang. The pointed morphology allows birds to insert the bill into pinyon cones to remove pine seeds with a forceps-like action (see Fig. 7 of Peterson 1993). This maneuver is more difficult with a hooked bill (Peterson 1993). Bardwell et al. (2001) experimentally confirmed that scrub-jays with pointed bills are more efficient at harvesting pinyon seeds than are jays with hooked bills. The relatively long, slender shape of the pointed bill significantly enhanced feeding efficiency, although the bill overhang had no measurable effect on efficiency. Since jays with pointed bills have a reduced bill overhang, we predicted that they would have more lice than jays with hooked bills. To test our prediction we analyzed louse load data from 170 freshly collected jays (Peterson 1990, 1992, 1993).

\section{METHODS}

Scrub-jays (65 pointed-billed, 105 hooked-billed) were collected at 10 sites (4 pinyon, 6 oak) across the western United States. Pointed-billed birds were collected from Yavapai County, Arizona ( $n=22$ birds), Clark $(n=23)$ and Lander $(n=11)$ Counties, Nevada, and Tooele Co., Utah $(n=9)$. Hooked-billed birds were collected from Monterey $(n=21)$, Orange $(n=16)$, Kern $(n=19)$, Contra Costa $(n=19)$, and Trinity $(n$ $=15$ ) Counties, California, and Benton Co., Oregon ( $n=15$; see Peterson 1990, 1992 for more information on sampling localities). Sites with mixed habitats (e.g., Edwards Plateau of Texas) and those near zones of contact between differentiated forms (e.g., northeastern California) were excluded from the analysis (Pitelka 1951).

Louse loads were measured using post-mortem ruffling (Clayton et al. 1992, Clayton and Drown 2001). Freshly killed birds were bagged individually and then sealed in an airtight container for 10-15 min with a cotton wad soaked in ethyl acetate. The plumage was then ruffled over a piece of white paper for at least 60 sec, with each major body region (wings, head, underparts, upperparts) ruffled for at least $15 \mathrm{sec}$. Lice were preserved in $70 \%$ ethanol, and later identified and counted. Values reported below are means \pm SE. 


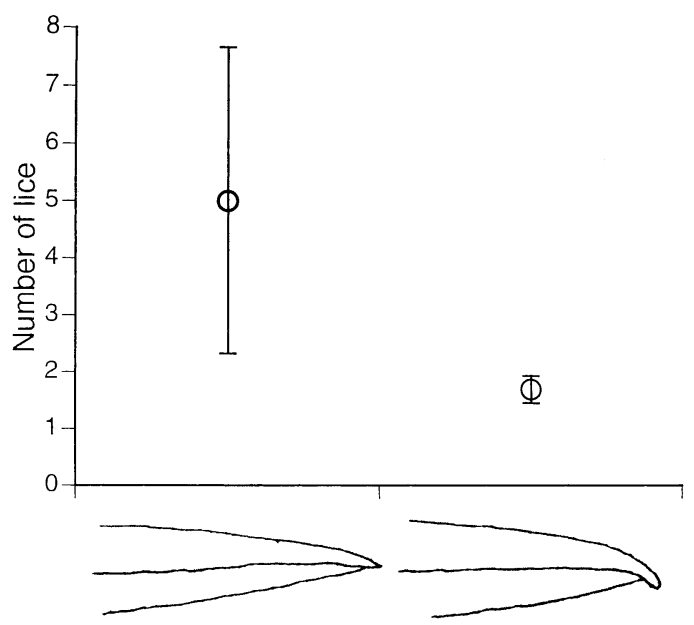

FIGURE 1. Relationship of bill morphology to mean $( \pm \mathrm{SE})$ number of lice recovered from infested Western Scrub-Jays (Aphelocoma californica) by post-mortem ruffling. Profiles (to scale) of pointed and hooked bills traced from Peterson (1993, CUniversity of Chicago Press, used with permission).

\section{RESULTS}

Three species of lice were found on the scrub-jays: Philopterus crassipes, Myrsidea sp., and Brueelia deficiens. The three species were pooled for the analyses in order to investigate how bill shape affected the overall louse community. Louse prevalence was $12 \%$ (21 of 170 jays had lice). The proportion of pointed-billed birds with lice (4 of $65 ; 6 \%$ ) was smaller than the proportion of hooked-billed birds with lice (17 of 105; $16 \%$; Fisher's exact test, $P=0.06$ ). Despite the small number of samples, infested birds with pointed bills had significantly more lice $(5.0 \pm 2.7)$ than did those with hooked bills $(1.7 \pm 0.2$; Mann-Whitney test, $Z=$ $1.9, P=0.05)$. Figure 1 shows the relationship of bill morphology to louse loads among infested birds.

\section{DISCUSSION}

These data are consistent with the prediction that jays with pointed bills are less efficient at preening than jays with hooked bills. This is not to say that individuals with pointed bills are completely incapable of controlling their louse loads. We excluded an infested, pointed-billed jay from our analyses because it was missing the entire distal half of its lower mandible. This bird, which was completely incapable of preening, had nearly twice as many lice $(n=22)$ as the next most infested bird in our study.

Factors in addition to bill morphology could conceivably have contributed to the difference in louse loads of pointed-billed and hooked-billed birds. For example, several studies have shown that large-bodied species of birds have more lice than small-bodied species, presumably because large-bodied hosts represent more abundant resources for lice (Gregory 1997, Rózsa 1997, Clayton and Walther 2001). The same relationship may hold within species, with larger-bodied populations or individuals having more lice. However, body size could not have confounded the results of the present study. Infested pointed-billed birds were significantly smaller $(n=4$, mean $=79.3 \pm 2.7 \mathrm{~g})$ than infested hooked-billed birds $(n=17$, mean $=93.7 \pm$ $2.4 \mathrm{~g}$; Mann-Whitney test, $Z=2.4, P<0.05$ ). In short, small jays actually had more lice than large jays.

Ambient humidity is another factor that can influence louse abundance. Moyer et al. (2002) showed that wild birds in arid habitats have significantly fewer lice than do conspecifics in humid habitats. To confirm humidity as the causal agent, they conducted an experiment with captive Rock Doves in which they manipulated ambient humidity. Louse infestations decreased dramatically on birds kept at low humidity, compared to birds at high humidity. The pinyon habitat of scrubjays with pointed bills was significantly drier (mean relative humidity $=35 \%$, range $20 \%$ to $47 \%, n=4$ ) than that of the oak habitat in which the hooked-billed birds were collected (mean $=62 \%$, range $39 \%$ to $76 \%$, $n=6$; comparison of National Weather Service average humidity near each site during the months of sampling: Mann-Whitney test, $Z=2.0, P<0.05)$. The risk of infestation was lower in pinyon habitat. Only $6 \%$ of jays (4 of 65) were infested in pinyon habitat, whereas $16 \%$ of jays (17 of 105) were infested in oak habitats.

The fact that infested pointed-billed birds had significantly more lice than infested hooked-billed birds, despite the former having smaller body size and living in more arid habitat, emphasizes the critical role of the bill overhang in preening for louse control. While Bardwell et al. (2001) demonstrated that the pointed bill shape of scrub-jays enhances feeding efficiency in pinyon habitats, our results suggest that pointed-billed birds incur a cost in terms of reduced preening efficiency.

The mean difference in lice on pointed- versus hooked-billed birds was only 3.3 lice. Could such a small difference have fitness consequences for the host? This is indeed possible for two reasons. First, the data shown are subsamples of lice removed by postmortem ruffling, which gets only a fraction of the lice on a bird (Clayton and Drown 2001). We estimated the total number of lice to be at least five times higher than the subsamples, which would be a mean of about 25 lice on pointed-billed and 8 lice on hooked-billed jays. This threefold difference could well translate into a significant difference in the energetic costs and fitness consequences of feather damage from lice (Booth et al. 1993, Clayton et al. 1999). Second, lice can vector pathogens and endoparasites (Saxena et al. 1985, Clayton and Adams, in press); all else being equal, the probability of infection by such agents increases with louse load.

Bill shape has traditionally been interpreted mainly in terms of foraging. Our results suggest that selection for efficient preening may also play a role in the evolution of bill shape. Research comparing the feeding and preening efficiencies of captive birds with different bill shapes could help determine the extent to which the evolution of bill shape has been governed by a feeding-preening tradeoff, rather than by trophic selection alone. 
The work on jays was supported by grants to ATP from NSF (BSR-8700850), the National Geographic Society, Field Museum of Natural History, and the Hinds Fund of the University of Chicago. DHC was supported by an NSF CAREER award (DEB9703003), and BRM was supported by grants from Sigma Xi and the Frank M. Chapman Memorial Fund of the American Museum of Natural History. We thank C. W. Benkman, J. Burtt, B. A. Walther, G. E. Woolfenden, and an anonymous referee for helpful comments on the manuscript. We are grateful to R. D. Price for identifying and counting the lice.

\section{LITERATURE CITED}

Bardwell, E., C. W. Benkman, and W. R. Gould. 2001. Adaptive geographic variation in Western Scrub-Jays. Ecology 82:2617-2627.

Benkman, C. W., And A. K. Lindholm. 1991. The advantages and evolution of a morphological novelty. Nature 349:519-520.

Booth, D. T., D. H. Clayton, and B. A. Block. 1993. Experimental demonstration of the energetic cost of parasitism in free-ranging hosts. Proceedings of the Royal Society of London Series B 253:125129.

Brown, N. S. 1972. The effect of host beak condition on the size of Menacanthus stramineus populations of domestic chickens. Poultry Science 51: $162-164$.

Campbell, B., And E. Lack [EDs.]. 1985. A dictionary of birds. T \& A D Poyser Ltd, Calton, UK.

Clayton, D. H. 1990. Mate choice in experimentally parasitized Rock Doves: lousy males lose. American Zoologist 30:251-262.

Clayton, D. H. 1991. Coevolution of avian grooming and ectoparasite avoidance, p. 258-289. In J. E. Loye and M. Zuk [EDs.], Bird-parasite interactions: ecology, evolution, and behaviour. Oxford University Press, Oxford, UK.

Clayton, D. H., AND R. J. Adams. In press. Chewing lice. In N. J. Thomas, C. T. Atkinson, and D. B. Hunter [EDS.], Infectious and parasitic diseases of wild birds. Iowa State University Press, Ames, IA.

Clayton, D. H., and P. Cotgreave. 1994. Relationship of bill morphology to grooming behaviour in birds. Animal Behaviour 47:195-201.

Clayton, D. H., and D. M. Drown. 2001. Critical evaluation of five methods for quantifying chewing lice (Insecta: Phthiraptera). Journal of Parasitology 87:1291-1300.

Clayton, D. H., R. D. Gregory, and R. D. Price. 1992. Comparative ecology of Neotropical bird lice. Journal of Animal Ecology 61:781-795.

Clayton, D. H., P. L. M. Lee, D. M. Tompkins, And E. D. BRoDIE. 1999. Reciprocal natural selection on host-parasite phenotypes. American Naturalist 154:261-270.
Clayton, D. H., and J. Moore [eds.]. 1997. Hostparasite evolution: general principles and avian models. Oxford University Press, Oxford, UK.

Clayton, D. H., AND B. A. Walther. 2001. Influence of host ecology and morphology on the diversity of Neotropical bird lice. Oikos 94:455-467.

GRANT, P. R. 1986. Ecology and evolution of Darwin's finches. Princeton University Press, Princeton, NJ

Gregory, R. D. 1997. Comparative studies of hostparasite communities, p. 198-211. In D. H. Clayton and J. Moore [EDS.], Host-parasite evolution: general principles and avian models. Oxford University Press, Oxford, UK.

LeHMANN, T. 1993. Ectoparasites: direct impact on host fitness. Parasitology Today 9:8-13.

Loye, J. E., AND M. ZuK [EDS.]. 1991. Bird-parasite interactions: ecology, evolution and behaviour. Oxford University Press, Oxford, UK.

Møller, A. P., K. Allander, And R. Dufva. 1990. Fitness effects of parasites on passerine birds: a review, p. 269-280. In J. Blondel, A. Gosler, J. Lebreton, and R. H. McCleery [EDS.], Population biology of passerine birds. Springer-Verlag, Berlin.

Moyer, B. R., D. M. Drown, and D. H. Clayton. 2002. Low humidity reduces ectoparasite pressure: Implications for host life history evolution. Oikos 97:223-228.

Moyer, B. R., A. J. Pacejka, and D. H. Clayton. In press. How birds combat ectoparasites. Current Ornithology.

Murray, M. D. 1990. Influence of host behaviour on some ectoparasites of birds and mammals, p. 290315. In C. J. Barnard and J. M. Behnke [EDS.], Parasitism and host behaviour. Taylor \& Francis, New York.

Peterson, A. T. 1990. Evolutionary relationships of the Aphelocoma jays. Ph.D. dissertation, University of Chicago, Chicago, IL.

Peterson, A. T. 1992. Phylogeny and rates of molecular evolution in the Aphelocoma jays (Corvidae). Auk 109:133-147.

Peterson, A. T. 1993. Adaptive geographical variation in bill shape of Scrub Jays (Aphelocoma coerulescens). American Naturalist 142:508-527.

Pitelka, F. A. 1951. Speciation and ecologic distribution in American jays of the genus Aphelocoma. University of California Publications in Zoology 50:195-464.

Pomeroy, D. E. 1962. Birds with abnormal bills. British Birds 55:49-72.

RózsA, L. 1997. Patterns in the abundance of avian lice (Phthiraptera: Amblycera, Ischnocera). Journal of Avian Biology 28:249-254.

Saxena, A. K., G. P. Agarwal, S. Chandra, and O. P. SingH. 1985. Pathogenic involvement of Mallophaga. Zeitschrift für Angewandte Entomologie 99:294-301.

SMITH, T. B. 1987. Bill size polymorphism and intraspecific niche utilization in an African finch. Nature 329:717-719. 